\title{
Proton-Pump Inhibitor and Tacrolimus use is Associated with Hypomagnesemia in Connective Tissue Disease: A Potential Pathogenic Link with Renal Deterioration and Recurrent Infections
}

Hironari Hanaoka ( $\nabla$ hhanaoka@keio.jp )

Keio University School of Medicine https://orcid.org/0000-0002-5172-1102

Jun Kikuchi

Keio University School of Medicine

Yuko Kaneko

Keio University School of Medicine

Noriyasu Seki

Mitsubishi Tanabe Pharma Cooperation

Hideto Tsujimoto

Mitsubishi Tanabe Pharma Cooperation

Kenji Chiba

Mitsubishi Tanabe Pharma Cooperation

Tsutomu Takeuchi

Keio University School of Medicine

Research article

Keywords: Proton pump inhibitor, tacrolimus, magnesium, hypomagnesemia, connective tissue disease

Posted Date: July 29th, 2020

DOI: https://doi.org/10.21203/rs.3.rs-49473/v1

License: (c) (i) This work is licensed under a Creative Commons Attribution 4.0 International License. Read Full License 


\section{Abstract}

Background: Low levels of serum magnesium (Mg) perturb renal tubular cell function and, lymphocyte resulting in renal deterioration and an imbalance in mononuclear cells. Here, we investigated the influence of hypomagnesaemia in patients with connective tissue disease (CTD).

Methods: We retrospectively evaluated CTD patients who visited our hospital during 2019 with available serum Mg levels. Patients were divided into two groups, those with or without hypomagnesemia $(<1.8$ $\mathrm{mg} / \mathrm{dL}$ ) and compared by rate of hospitalization for severe infection and cumulative renal deterioration. They were also compared by fractions of lymphocytes, and natural killer (NK) and dendritic cell (DC) subsets as measured by fluorescence-activated cell sorting (FACS) analysis.

Results: Among 284 patients, hypomagnesemia was detected in 63 (22.2\%). Multivariate analysis revealed that use of proton-pump inhibitors (PPIs) (OR 1.48, $\mathrm{p}=0.01$ ) and tacrolimus (TAC) (OR 6.14, $p<0.01)$ was independently associated with hypomagnesaemia. Renal deterioration rate was significantly higher in TAC and/or PPI users with hypomagnesemia $(p=0.01)$. Hospitalization rate for severe infection was also higher in patients with hypomagnesaemia $(p=0.04)$. FACS analysis showed lower counts for CD8+ T cells, CD19+ B cells, NK cells, and DC in hypomagnesaemia $(p=0.03, p=0.02, p=0.02$, and $p=0.03$, respectively).

Conclusions: Use of TAC and PPIs may be associated with hypomagnesaemia and lead to poor renal outcomes and severe infection in CTD.

\section{Background}

Magnesium (Mg) is an abundant intracellular cation which acts as a co-factor for more than 300 enzymes involved in a number of fundamental functions. Mg deficiency leads to many pathogenic conditions, including cardiovascular mortality, stroke, chronic kidney disease (CKD) progression, osteoporosis, and insulin resistance [1-6]. Hypomagnesemia is also associated with the development of recurrent infections due to its role a second messenger in $\mathrm{T}$ cell activation and contribution to the cytotoxicity of natural killer (NK) and CD8 + T cells. [7-9].

Causes of hypomagnesemia are categorized into three groups: decreased dietary intake, impaired gastrointestinal absorption, and increased renal loss [10]. Several medications are known to influence serum Mg levels through these mechanisms. Proton-pump inhibitors (PPIs) inhibit pH-dependent active Mg absorption via transient receptor potential melastatin (TRPM) 6 and 7 channels in the intestine [11]. Calcineurin inhibitors (CNIs) are also associated with low serum $\mathrm{Mg}$ concentrations [12, 13]. In kidney transplantation recipients, CNls decrease serum Mg concentrations rapidly and profoundly by wasting Mg through inhibition of TRPM6 in the renal tubule. CNIs interfere with TRPM6 in the renal tubule, but do not alter TRPM6 function in the intestine [14]. However, although both PPIs and CNIs, including tacrolimus (TAC), are frequently used in patients with connective tissue diseases (CTDs) [15-22], little is known about the influence of these drugs on serum levels of $\mathrm{Mg}$ in the management of CTDs. 
The aim of this study was to investigate the prevalence of hypomagnesemia and its clinical impact on patients with CTD in relation to PPIs and TAC.

\section{Material And Methods}

\section{Patients and evaluation of clinical data}

We reviewed consecutive patients who visited Keio University Hospital from January 2019 to December 2019 and were diagnosed with rheumatoid arthritis (RA), systemic lupus erythematosus (SLE), polymyositis/dermatomyositis (PM/DM), Sjögren syndrome (SS), systemic sclerosis (SSc), mixed connective tissue disease (MCTD), anti-neutrophil cytoplasmic antibodies-related vasculitis and other rheumatic diseases according to the respective classification criteria [23-37]. Patients with available serum Mg levels were included in the study. We collected clinical characteristics, treatments administered for more than 3 years, laboratory data, estimated glomerular filtration rate (eGFR), and hospitalization due to infection from diagnosis to December 2019.

This study was approved by the Ethics Committee of Keio University School of Medicine. Blood samples for flow cytometric analysis were obtained after the subjects gave written informed consent, as approved by the Institutional Review Board.

\section{Definition}

Hypomagnesemia was defined as a serum $\mathrm{Mg}$ concentrations $<1.8 \mathrm{mg} / \mathrm{dL}$ [38]. Renal deterioration was defined as a greater than $30 \%$ decline in serum creatinine levels from baseline [39]. Fractional excretion of $\mathrm{Mg}\left(\mathrm{FEMg}\right.$, \%) was calculated with the following formula: $\mathrm{FE}_{\mathrm{Mg}}=\left(\mathrm{U}_{\mathrm{Mg}}{ }^{*} \mathrm{P}_{\mathrm{Cr}}\right) /\left(0.7{ }^{*} \mathrm{P}_{\mathrm{Mg}}{ }^{*} \mathrm{U}_{\mathrm{Cr}}\right){ }^{\star} 100$ [40], where $U$ and $P$ refer to the urine and plasma concentrations of $\mathrm{Mg}$ and creatinine $(\mathrm{Cr})$, respectively. Serum $\mathrm{Mg}$ concentration was multiplied by 0.7 , as only about $70 \%$ of circulating magnesium is free and filtered across the glomerulus. Normal limit of FEMg is defined as less than $2 \%$ [40].

\section{TAC measurement}

TAC concentration in fresh whole blood samples collected 12 hours after the last TAC administration was measured by the TACR Flex Dimension immunoassay method using a Dimension EXL analyzer (Siemens Healthcare Diagnostics, Tokyo, Japan) [17].

\section{Flow cytometry}

Blood samples at the time of serum Mg measurement from our cell bank of RA patients treated with methotrexate (MTX) monotherapy were analyzed with fluorescence-activated cell sorting. Samples were stained with antibodies (BD Biosciences and BioLegend; Table S1) and fixed by Phosflow Lyse/Fix Buffer (BD Bioscience). Flow cytometric analysis was conducted on an LSRFortessa ${ }^{\mathrm{TM}} \mathrm{X}-20$ (Becton Dickinson) and analyzed by FlowJo ver.10 (FlowJo LLC). Phenotypes of immune cell subsets were defined based on the Human Immunology Project protocol (Table S2) [41]. Mean numbers of each immune cell phenotype were compared. 


\section{Statistical analysis}

Continuous values are shown as median and interquartile range (IQR). Comparisons between two groups were performed with the Mann-Whitney U-test for continuous variables and the chi-squared test or Fisher's exact test for categorical variables. Four groups were compared by analysis of variance. Cumulative renal deterioration rates were analyzed by the Kaplan-Meier method with the log-rank test. Correlations of two continuous variables were analyzed with the Spearman rank correlation coefficient. To identify independent parameters, binary logistic regression analysis was used with variables having a P-value $<0.005$ in a previous univariate analysis as covariates. A P-value $<0.05$ was defined as statistically significant.

\section{Results}

\section{Clinical characteristics}

A total of 284 patients with CTD were included in the study. Median (IQR) age was 64.0 (48.0-73.0) years and $83.8 \%$ were female (Table 1). Underlying CTDs were RA in 108 patients (38.0\%), SLE in $59(20.8 \%)$, PM/DM in 20 (7.0\%), SSc in 24 (8.5\%) MCTD in 10 (3.5\%), polymyalgia rheumatica in 10 (3.5\%), microscopic polyangiitis in 8 (2.8\%), IgG4-related disease in 9 (3.2\%), SS in 6 (2.1\%), adult Still's disease in $6(2.1 \%)$, arthritis with palmoplantar pustulosis in $6(2.1 \%)$, eosinophilic granulomatous polyangiitis in $4(1.4 \%)$, psoriatic arthritis in $4(1.4 \%)$, sarcoidosis in $2(0.7 \%)$, Takayasu's arteritis in $2(0.7 \%)$, granulomatous polyangiitis in $2(0.8 \%)$, Behçet's disease in $2(0.8 \%)$, diffuse fasciitis in $2(0.8 \%)$, and familial Mediterranean fever in $1(0.4 \%)$. Glucocorticoid was used by $41.5 \%$ of total patients and median (IQR) dose was 0.0 (0.0-4.0) mg/day. Among all patients, 141 (49.6\%) used PPIs and 68 (23.9\%) used TAC. Hospitalization for severe infection was seen in 25 (8.8\%) patients. Hypomagnesemia was observed in $63(22.2 \%)$ patients. 
Table 1

Patients characteristics

\begin{tabular}{|c|c|c|c|c|}
\hline & $\begin{array}{l}\text { All } \\
(n=284)\end{array}$ & $\begin{array}{l}\text { Normal Mg } \\
(n=221)\end{array}$ & $\begin{array}{l}\text { Hypomagnesemia } \\
(n=63)\end{array}$ & $\mathbf{p}$ \\
\hline Age, years & $64.0(48.0-73.0)$ & $71.0(51.0-74.0)$ & $55.0(38.0-69.0)$ & 0.029 \\
\hline Male:Female & $46: 238$ & $35: 186$ & $11: 52$ & 0.752 \\
\hline \multicolumn{5}{|c|}{ Underlying disease } \\
\hline RA (\%) & $108(38.0)$ & $94(42.5)$ & $14(22.2)$ & \\
\hline SLE (\%) & $59(20.8)$ & $36(16.3)$ & $23(36.5)$ & \\
\hline PM/DM (\%) & $20(7.0)$ & $11(4.9)$ & $9(14.2)$ & \\
\hline SSc (\%) & $24(8.5)$ & $23(10.4)$ & $1(1.6)$ & \\
\hline MCTD (\%) & $10(3.5)$ & $9(4.1)$ & $1(1.6)$ & \\
\hline PMR (\%) & $10(3.5)$ & $7(3.2)$ & $3(4.8)$ & \\
\hline Others* $(\%)$ & $53(18.7)$ & $41(18.6)$ & $12(19.0)$ & \\
\hline \multicolumn{5}{|c|}{ Serum electrolytes } \\
\hline $\mathrm{Mg}, \mathrm{mg} / \mathrm{dL}$ & $2.1(1.9-2.2)$ & $2.1(2.0-2.2)$ & $1.7(1.7-1.8)$ & $\begin{array}{l}< \\
0.001\end{array}$ \\
\hline $\mathrm{Na}, \mathrm{mEq} / \mathrm{L}$ & $\begin{array}{l}140.9(139.7- \\
142.3)\end{array}$ & $\begin{array}{l}141.2(139.8- \\
142.4)\end{array}$ & $\begin{array}{l}140.5(139.3- \\
141.9)\end{array}$ & 0.163 \\
\hline $\mathrm{K}, \mathrm{mEq} / \mathrm{L}$ & $4.2(3.9-4.4)$ & $4.2(4.0-4.4)$ & $4.1(3.9-4.3)$ & 0.087 \\
\hline $\mathrm{CL}, \mathrm{mEq} / \mathrm{L}$ & $\begin{array}{l}105.0(104.0- \\
107.0)\end{array}$ & $\begin{array}{l}106.0(104.0- \\
107.0)\end{array}$ & $\begin{array}{l}105.0(103.0- \\
106.0)\end{array}$ & 0.241 \\
\hline $\mathrm{Ca}, \mathrm{mEq} / \mathrm{L}$ & $9.2(8.9-9.4)$ & $9.1(8.9-9.4)$ & $9.2(8.9-9.4)$ & 0.608 \\
\hline $\mathrm{P}, \mathrm{mEq} / \mathrm{L}$ & $3.5(3.2-3.9)$ & $3.5(3.2-3.9)$ & $3.5(3.1-3.9)$ & 0.489 \\
\hline
\end{tabular}

Results show median (interquartile range) unless otherwise indicated.

*Others include microscopic polyangiitis, IgG4-related disease, Sjogren syndrome, adult Still's disease, arthritis with palmoplantar pustulosis, eosinophilic granulomatous polyangiitis, psoriatic arthritis, sarcoidosis, Takayasu's arteritis, granulomatous polyangiitis, Behçet's disease, diffuse fasciitis, and familial Mediterranean fever.

Mg, magnesium; RA, rheumatoid arthritis; SLE, systemic lupus erythematosus; SSc, systemic sclerosis; MCTD, mixed connective tissue disease; PMR, polymyalgia rheumatica; eGFR, estimated glomerular filtration rate; L-FABP, liver-type fatty acid binding protein; NAG, N-acetyl- $\beta$-Dglucosaminidase; NGAL, neutrophil gelatinase-associated lipocalin; GC, glucocorticoid; PPIs, protonpump inhibitors; TAC, tacrolimus; MMF, mycophenolate mofetil; MTX, methotrexate; AZA, azathioprine; $\mathrm{HCQ}$, hydroxychloroquine. 


\begin{tabular}{|c|c|c|c|c|}
\hline & $\begin{array}{l}\text { All } \\
(n=284)\end{array}$ & $\begin{array}{l}\text { Normal Mg } \\
(\mathrm{n}=221)\end{array}$ & $\begin{array}{l}\text { Hypomagnesemia } \\
(n=63)\end{array}$ & $\mathbf{p}$ \\
\hline eGFR, $\mathrm{ml} / \mathrm{min} / 1.73 \mathrm{~m}^{2}$ & $68.0(56.0-80.0)$ & $63.0(56.0-80.0)$ & $70.0(56.0-81.0)$ & 0.462 \\
\hline \multicolumn{5}{|l|}{ Urine markers } \\
\hline$\beta 2$-microglobulin, $\times 10^{2} \mu \mathrm{g} / \mathrm{L}$ & $1.5(0.9-2.9)$ & $2.1(0.9-3.2)$ & $1.2(0.7-1.9)$ & 0.386 \\
\hline a1-microglobulin, mg/L & $3.3(1.6-6.5)$ & $3.8(1.6-6.9)$ & $3.3(1.6-5.8)$ & 0.636 \\
\hline L-FABP, $\mu \mathrm{g} / \mathrm{g} \square \mathrm{Cre}$ & $2.4(1.6-4.7)$ & $3.1(1.7-4.8)$ & $2.2(1.4-4.4)$ & 0.164 \\
\hline NAG, IU/L & $5.0(2.5-8.2)$ & $5.0(2.4-8.1)$ & $5.3(3.4-9.6)$ & 0.120 \\
\hline NGAL, $\mu g / g \square C r e$ & $21.7(14.0-38.5)$ & $21.7(15.1-37.1)$ & $21.7(12.9-46.0)$ & 0.770 \\
\hline \multicolumn{5}{|l|}{ Medication } \\
\hline GC, (\%) & $118(41.5)$ & $78(35.3)$ & $40(63.4)$ & 0.001 \\
\hline $\begin{array}{l}\text { GC dose, median (IQR) } \\
\text { mg/day }\end{array}$ & $0(0-4)$ & $0(0-3)$ & $3(0-5)$ & 0.001 \\
\hline TAC (\%) & $68(23.9)$ & $34(15.3)$ & $34(53.9)$ & 0.001 \\
\hline MMF (\%) & $13(4.6)$ & $6(2.7)$ & $7(11.1)$ & 0.006 \\
\hline MTX (\%) & $81(28.5)$ & $71(32.1)$ & $10(15.9)$ & 0.001 \\
\hline AZA (\%) & $19(6.7)$ & $17(7.6)$ & $2(3.2)$ & 0.213 \\
\hline HCQ (\%) & $27(9.5)$ & $13(5.9)$ & $14(22.2)$ & 0.001 \\
\hline PPI (\%) & $141(49.6)$ & $93(42.1)$ & $48(76.1)$ & 0.001 \\
\hline $\begin{array}{l}\text { Hospitalization due to } \\
\text { infection }\end{array}$ & $25(8.8)$ & $15(6.7)$ & 10 (15.8) & 0.042 \\
\hline \multicolumn{5}{|c|}{ Results show median (interquartile range) unless otherwise indicated. } \\
\hline \multicolumn{5}{|c|}{$\begin{array}{l}\text { *Others include microscopic polyangiitis, IgG4-related disease, Sjogren syndrome, adult Still's disease, } \\
\text { arthritis with palmoplantar pustulosis, eosinophilic granulomatous polyangiitis, psoriatic arthritis, } \\
\text { sarcoidosis, Takayasu's arteritis, granulomatous polyangiitis, Behçet's disease, diffuse fasciitis, and } \\
\text { familial Mediterranean fever. }\end{array}$} \\
\hline \multicolumn{5}{|c|}{$\begin{array}{l}\text { Mg, magnesium; RA, rheumatoid arthritis; SLE, systemic lupus erythematosus; SSc, systemic } \\
\text { sclerosis; MCTD, mixed connective tissue disease; PMR, polymyalgia rheumatica; eGFR, estimated } \\
\text { glomerular filtration rate; L-FABP, liver-type fatty acid binding protein; NAG, N-acetyl- } \beta \text {-D- } \\
\text { glucosaminidase; NGAL, neutrophil gelatinase-associated lipocalin; GC, glucocorticoid; PPIs, proton- } \\
\text { pump inhibitors; TAC, tacrolimus; MMF, mycophenolate mofetil; MTX, methotrexate; AZA, } \\
\text { azathioprine; HCQ, hydroxychloroquine. }\end{array}$} \\
\hline
\end{tabular}

\section{Factors associated with hypomagnesemia}


The patients were divided into two groups according to the presence of hypomagnesemia. Clinical characteristics were compared between the normal $M g(n=221)$ and hypomagnesemia groups $(n=63)$ (Table 1). Median age was significantly higher in the normal $\mathrm{Mg}$ group than in the hypomagnesemia group (71.0 years vs 55.0 years, $p=0.029$, respectively). Renal function, electrolyte concentrations except for $\mathrm{Mg}$, and urine markers were not different between the two groups. Rates of use of glucocorticoid, PPI, TAC, mycophenolate mofetil (MMF), and hydroxychloroquine (HCQ) were significantly lower in the normal $\mathrm{Mg}$ group than in the hypomagnesemia group (glucocorticoid, $35.3 \%$ vs $63.4 \%, p=0.001 ; \mathrm{PPI}, 42.1 \%$ vs $76.1 \%, p=0.001$; TAC, $15.3 \%$ vs $53.9 \%, p=0.001 ;$ MMF, $2.7 \%$ vs $11.1 \%, p=0.006$; HCQ, $5.9 \%$ vs $22.2 \%, p=$ 0.001 , respectively). Use of MTX was significantly higher in the normal Mg group (32.1\% vs $15.9 \%, p=$ $0.001)$.

Hospitalization due to severe infection from the diagnosis of CTDs to December 2019 occurred significantly less frequently in the normal $\mathrm{Mg}$ group than in the hypomagnesemia group (6.7\% vs $15.8 \%$, $p=0.042)$.

Multiple logistic regression analysis identified the use of PPI (odds ratio 1.45, confidence interval 1.0-3.29, $p=0.009$ ) and TAC (odds ratio 5.99, confidence interval 2.93-12.24, $p<0.001$ ) as independent factors associated with hypomagnesemia (Table 2).

Table 2

Multivariate analysis for factors associated with hypomagnesemia

\begin{tabular}{|lll|}
\hline Factor & Odds ratio $(95 \% \mathrm{Cl})$ & $\mathbf{p}$ \\
\hline Age & $0.96(0.95-1.05)$ & 0.152 \\
\hline SLE & $1.47(0.54-3.97)$ & 0.445 \\
\hline RA & $0.84(0.32-2.16)$ & 0.727 \\
\hline GC use & $1.14(0.49-2.71)$ & 0.753 \\
\hline PPI use & $1.45(1.01-3.29)$ & 0.009 \\
\hline TAC use & $5.99(2.93-12.24)$ & $<0.001$ \\
\hline MTX use & $0.72(0.27-1.95)$ & 0.523 \\
\hline HCQ use & $1.71(0.53-5.52)$ & 0.371 \\
\hline $\begin{array}{l}\text { SLE, systemic lupus erythematosus; RA, rheumatoid arthritis; GC, glucocorticoid; PPIs, proton-pump } \\
\text { inhibitors; TAC, tacrolimus; MTX, methotrexate; HCQ, hydroxychloroquine. }\end{array}$ \\
\hline
\end{tabular}

\section{Association of drugs and $\mathrm{Mg}$ levels}

To investigate the effect of TAC and PPI on serum Mg levels further, we divided all patients into 4 groups according to the use of TAC and PPI (Fig. 1A) and compared magnesium levels. Median (IQR) levels of serum Mg were 2.1 (2.0-2.2) $\mathrm{mg} / \mathrm{dL}$ in patients without TAC and PPI, 2.1 (1.9-2.2) $\mathrm{mg} / \mathrm{dL}$ in those with 
only PPI, $1.9(1.8-1.9) \mathrm{mg} / \mathrm{dL}$ in those with only TAC, and $1.8(1.8-2.9) \mathrm{mg} / \mathrm{dL}$ in those with both TAC and PPI $(p<0.0001)$.

We then calculated FEMg in patients with hypomagnesemia $(n=57)$ (Fig. 1B). The FEMg was $1.7(1.5-$ 2.7)\% in those without TAC and PPI, $2.2(1.6-3.2) \%$ in those with only PPI, 3.9 (2.6-4.9)\% in those with only TAC, and $2.7(1.3-4.7) \%$ in those with both TAC and PPI $(p=0.04)$, reflecting the different mechanisms of causation of hypomagnesemia, namely that TAC inhibits reabsorption of $\mathrm{Mg}$ in the kidneys with a consequent increase in excretion of $\mathrm{Mg}$ in urine, and that PPI causes wasting of $\mathrm{Mg}$ in the intestine.

The relationship of serum TAC concentrations with serum Mg levels and FEMg corroborated the effect of the drugs. In patients who did not use PPI, TAC concentrations were negatively correlated with Mg levels $(r=-0.61, p<0.01$, Fig. 2A) and positively with FEMg $(r=0.38, p=0.05$, Fig. 2B). In patients who used PPI, these correlations disappeared (Mg levels, $r=-0.25, p=0.19$, Fig. 2C; FEMg, $r=-0.07, p=0.73$, Fig. 2D). We further investigated 28 patients who had discontinued PPI at the attending physician's discretion (without tacrolimus, $n=22$; with tacrolimus, $n=6$ ): in patients who did not use TAC, serum Mg levels were significantly increased after PPI discontinuation from $2.0(2.0-2.2) \mathrm{mg} / \mathrm{dL}$ to $2.2(2.0-2.4) \mathrm{mg} / \mathrm{dL}, \mathrm{p}=0.04$, Fig. 3A), while FEMg did not change (from $1.9[1.4-2.7] \%$ to $2.2[1.9-2.7] \%, p=0.16$, Fig. 3B); in patients treated with TAC, in contrast, serum Mg concentrations and FEMg were not changed (Mg, 1.8 [1.6-3.0] $\mathrm{mg} / \mathrm{dL}$ to $2.0[1.6-4.6] \mathrm{mg} / \mathrm{dL}, \mathrm{p}=0.82$, Fig. 3C; FEMg, $2.3[1.3-3.0] \%$ to $2.1[1.6-8] \%, p=0.56$, Fig. 3D).

\section{Relationship between hypomagnesemia and renal deterioration}

As the use of TAC and PPI was the major cause of hypomagnesemia, we investigated the sequential renal function of patients treated with TAC and/or PPI $(n=173)$ from the initiation of these drugs until the last observation. When we divided the patients according to the presence of hypomagnesemia, the cumulative renal deterioration-free rates were significantly higher in patients with normal $\mathrm{Mg}(\mathrm{n}=124$; 80.7\%; observation period, $5.0 \pm 2.9$ years) than in those with hypomagnesemia $(n=49,65.7 \%$, observation period, $5.3 \pm 3.4$ years) ( $p=0.007$, Fig. 4). Of note, renal deterioration was not related with TAC use (renal deterioration-free at last observation, TAC users $84.5 \%$ and non-TAC users $90.1 \%, p=0.34$ ).

\section{Effect of hypomagnesemia on immune cells}

Among the 283 patients enrolled in this study, 17 patients who were also registered in another cohort of our university had information on peripheral blood mononuclear cells analyzed with FACS at the time $\mathrm{Mg}$ concentrations were measured. All 17 of these patients had RA and were treated with methotrexate alone. Six of these 17 patients had hypomagnesemia while the other 11 had normal Mg levels. These patients did not differ with regard to sex, disease duration, disease activity, or MTX dose (Table S3). In contrast, numbers of CD8 $+T$ cells, CD19 + B cells, NK cells, and DC were significantly lower in the patients with hypomagnesemia than in the patients with normal $\operatorname{Mg}(p=0.03, p=0.02, p=0.02$, and $p=0.03$, 
respectively, Fig. 5). Hospitalization due to infection was observed in 1 patient with hypomagnesemia $(16.6 \%)$ and 1 with normal $\mathrm{Mg}(9.1 \%)(p=0.64)$.

\section{Discussion}

In our study, hypomagnesemia was observed in approximately one-fifth of patients with CTD and was associated with renal deterioration and hospitalization due to severe infections. The development of hypomagnesemia might have been caused by the use of TAC and PPIs.

Our study showed a high renal deterioration rate in patients with hypomagnesemia. This finding is consistent with previous studies which reported the association of hypomagnesemia with incident CKD [42], a decline in eGFR in CKD patients [43], and progression to end-stage renal disease in diabetic nephropathy [44]. Laecke et al investigated 1,650 patients with CKD with a median follow-up of 5.1 years and reported that a 1-mg/dL decrease in baseline serum $\mathrm{Mg}$ was associated with a yearly decrease in eGFR of $5.1 \%$. Another report in Japanese patients with diabetic nephropathy $(n=144)$ showed that patients with hypomagnesemia were twice as likely to progress to end-stage renal disease compared to those with a normal range. The pathogenic mechanism of hypomagnesemia related to renal deterioration is not fully understood, but hypomagnesemia is considered to damage renal tubules. In one study, incubation of tubular epithelial cells in low-Mg medium increased the rate of apoptosis, whereas this effect was significantly suppressed when Mg concentration was increased [45].

In our study, $22.2 \%$ of patients with CTDs showed serum magnesium levels below $1.8 \mathrm{mg} / \mathrm{dL}$. Low levels were associated with a high hospitalization rate due to severe infection. An association of hypomagnesemia and recurrent infection has been reported. Patients with X-linked XMEN, a hereditary immune deficiency syndrome in which dysfunction of the magnesium channel MAGT1 in T lymphocytes leads to a low intra-lymphocytic free magnesium concentration, suffer from recurrent infection [46]. Hypomagnesemic rats were shown to die earlier than control rats when injected with intravenous Escherichia coli endotoxin, whereas magnesium supplementation improve survival [47]. In a clinical report on kidney transplantation, low serum $\mathrm{Mg}$ was associated with an increased hazard of infection, and every $0.1 \mathrm{mg} / \mathrm{dL}$ reduction in serum magnesium below $2.0 \mathrm{mg} / \mathrm{dL}$ increased the hazard ratio by $15 \%$ [48]. Hypomagnesemia decreases T cell numbers, activation, and the cytotoxicity of CD8 + T cells and NK cells [49]. Although this study did not examine lymphocyte function, we did identify a decrease in the number of CD $8+T$ cells, CD19 + B cells, NK cells, and DC in RA patients with hypomagnesemia. Taken together, the decreased function and number of mononuclear cells caused by hypomagnesemia may be associated with the impaired immune function in hypomagnesemia.

Hypomagnesemia in patients with CTD was significantly associated with the use of TAC and PPIs in our study. These findings are consistent with the action of these drugs, namely with TAC's interference with Mg-reabsorption from urine and PPIs interference with $\mathrm{Mg}$ absorption from the intestines [11-13]. Of the two drugs, TAC's interference on systemic Mg transportation is much stronger than that of PPIs, given that the reabsorption of $\mathrm{Mg}$ in the kidneys can handle 20 -fold greater amounts of dietary $\mathrm{Mg}$ than 
absorption from the intestines [1]. In fact, our study showed that patients using TAC had lower Mg concentrations than those using PPIs, but that the combination use of PPIs and TAC did not show any additional lowering effect on $\mathrm{Mg}$ concentration than TAC use alone. In our study, the discontinuation of PPI increased Mg levels in patients without TAC, suggesting that hypomagnesemia caused by PPIs is reversible. We therefore recommend the monitoring of serum Mg levels in patients treated with PPIs, and consideration of the discontinuation when hypomagnesemia emerges. As for patients treated with TAC, Mg levels did not change when PPIs were stopped. We speculate that this is due to the far stronger effect of TAC than PPIs on lowering serum Mg levels. However, while we cannot conclude that serum $\mathrm{Mg}$ concentration would increase after TAC discontinuation because no patient discontinued TAC in our study, we can say that TAC dose should be reduced by monitoring TAC concentration to as low as possible to prevent hypomagnesemia, given our findings that TAC concentrations were negatively correlated with serum $\mathrm{Mg}$ concentrations.

Our study has several limitations. First, it is a retrospective, single-centered cohort with a small sample size. This could have caused a degree of selection bias. Second, serum magnesium levels were measured cross-sectionally. Changes in magnesium levels over the period of observation of renal function were therefore unclear, which weakened the discussion about the relationship between hypomagnesemia and renal deterioration. Third, PPI was discontinued at the discretion of the attending physicians, which may have resulted in a degree of selection bias. Confirmation of our findings will require a multi-center prospective study.

\section{Conclusions}

The use of TAC and PPIs was associated with hypomagnesaemia and led to poor renal outcomes and severe infection in patients with CTDs. The lowest possible dose of TAC should be prescribed in the management of CTDs, and the need for PPIs should be periodically reassessed.

\section{List of abbreviations}

Mg, magnesium; CTD, connective tissue disease; NK, natural killer; DC, dendritic cell; FACS, fluorescenceactivated cell sorting; PPIs, proton-pump inhibitors; TAC, tacrolimus; CKD, chronic kidney disease; TRPM, transient receptor potential melastatin; CNIs, calcineurin inhibitors; RA, rheumatoid arthritis; SLE, systemic lupus erythematosus; PM/DM, polymyositis/dermatomyositis; eGFR; estimated glomerular filtration rate; $\mathrm{FE}$, fractional excretion; $\mathrm{Cr}$, creatinine; MTX, methotrexate; ESRD, end-stage renal disease.

\section{Declarations}

\section{Declarations}

\section{Ethics approval and consent to participate}


This study was approved by the Ethics Committee of Keio University School of Medicine. We obtained informed written consent from all subjects prior to collecting samples in accordance with the tenets of the Declaration of Helsinki.

\section{Consent for publication}

Not applicable

\section{Availability of data and materials}

The datasets analyzed during the current study are available from the corresponding author upon reasonable request.

\section{Competing interests}

None

\section{Funding}

None

\section{Authors' contributions}

H.H. performed the majority of research and analyzed and interpreted the data; N.S., K.T., and K.C. performed the FACS analysis; J.K. and Y.K. collected patient's data and samples; T.T. designed the research, interpreted the data and supervised and organized the study; all authors wrote the manuscript. All authors read and approved the final manuscript.

\section{Acknowledgements}

None

\section{References}

1. Al Alawi AM, Majoni SW, Falhammar H. Magnesium and Human Health: Perspectives and Research Directions. Int J Endocrinol. 2018: 9041694.

2. He K, Liu K, Daviglus ML, Morris SJ, Loria CM, Van Horn L, et al. Magnesium intake and incidence of metabolic syndrome among young adults. Circulation. 2006;113:1675-82.

3. Ohira T, Peacock JM, Iso H, Chambless LE, Rosamond WD, Folsom AR. Serum and dietary magnesium and risk of ischemic stroke: the Atherosclerosis Risk in Communities Study. Am J Epidemiol. 2009;169,:1437-44.

4. T. D. Mountokalakis. Magnesium metabolism in chronic renal failure. Magnesium Research. 1990; 3:121-127. 
5. Castiglioni S, Cazzaniga A, Albisetti W, Maier JA. Magnesium and osteoporosis: current state of knowledge and future research directions. Nutrients. 2013;5:3022-33.

6. Kao WH, Folsom AR, Nieto FJ, Mo JP, Watson RL, Brancati FL. Serum and dietary magnesium and the risk for type 2 diabetes mellitus: the atherosclerosis risk in communities study. Arch Intern Med. 1999;159:2151-9.

7. Li FY, Chaigne-Delalande B, Kanellopoulou C, Davis JC, Matthews HF, Douek DC, et al. Second messenger role for Mg2 + revealed by human T-cell immunodeficiency. Nature. 2011;475:471-6.

8. Chaigne-Delalande B, Li FY, O'Connor GM, Lukacs MJ, Jiang P, Zheng L, et al. Mg2 + regulates cytotoxic functions of NK and CD8 T cells in chronic EBV infection through NKG2D. Science. 2013;341:186-91.

9. Mazur A, Maier JAM, Rock E, Gueux E, Nowacki W, Rayssiguier Y. Magnesium and the inflammatory response: potential physiopathological implications. Arch Biochem Biophys. 2007;458:48-56.

10. Blaine J, Chonchol M, Levi M. Renal control of calcium, phosphate, and magnesium homeostasis. Clin J Am Soc Nephrol. 2015;10:1257-72.

11. Perazella MA. Proton pump inhibitors and hypomagnesemia: a rare but serious complication. Kidney Int. 2013;83:553-6.

12. Barton $\mathrm{CH}$, Vaziri ND, Martin DC, Choi S, Alikhani S. Hypomagnesemia and renal magnesium wasting in renal transplant recipients receiving cyclosporine. Am J Med. 1987;83:693-9.

13. Navaneethan SD, Sankarasubbaiyan S, Gross MD, Jeevanantham V, Monk RD. Tacrolimusassociated hypomagnesemia in renal transplant recipients. Transplant Proc. 2006;38:1320-2.

14. Gouadon E, Lecerf F, German-Fattal M. Differential effects of cyclosporin A and tacrolimus on magnesium influx in Caco2 cells. J Pharm Pharm Sci. 2012;15:389-98.

15. Kaneko Y, Kawahito Y, Kojima M, Nakayama T, Hirata S, Kishimoto M, et al. Efficacy and safety of tacrolimus in patients with rheumatoid arthritis - A systematic review and meta-analysis. Mod Rheumatol. 2020;30:1-9.

16. Takeuchi T, Kawai S, Yamamoto K, Harigai M, Ishida K, Miyasaka N. Post-marketing surveillance of the safety and effectiveness of tacrolimus in 3,267 Japanese patients with rheumatoid arthritis. Mod Rheumatol. 2014;24:8-16.

17. Takahashi S, Hiromura K, Sakurai N, Matsumoto T, Ikeuchi H, Maeshima A, et al. Efficacy and safety of tacrolimus for induction therapy in patients with active lupus nephritis. Mod Rheumatol. 2011;21:282-9.

18. Mok CC. Pro. The use of calcineurin inhibitors in the treatment of lupus nephritis. Nephrol Dial Transplant. 2016;31:1561-6.

19. Mok CC, Ying KY, Yim CW, Siu YP, Tong KH, To CH, et al. Tacrolimus versus mycophenolate mofetil for induction therapy of lupus nephritis: a randomized controlled trial and long-term follow-up. Ann Rheum Dis. 2016;75:30-6. 
20. Takada K, Katada Y, Ito S, Hayashi T, Kishi J, Itoh K, et al. Impact of adding tacrolimus to initial treatment of interstitial pneumonitis in polymyositis/dermatomyositis: a single-arm clinical trial. Rheumatology (Oxford).2019 in press.

21. Hanaoka H, lida H, Kiyokawa T, Takakuwa Y, Kawahata K. Mycophenolate mofetil treatment with or without a calcineurin inhibitor in resistant inflammatory myopathy. Clin Rheumatol. 2019;38:585-90.

22. Ueno KI, Shimojima Y, Kishida D, Sekijima Y, Ikeda SI. Advantage of administering tacrolimus for improving prognosis of patients with polymyositis and dermatomyositis. Int $\mathrm{J}$ Rheum Dis. 2016;19:1322-30.

23. Aletaha D, Neogi T, Silman AJ, Funovits J, Felson DT, Bingham CO 3rd, et al. 2010 rheumatoid arthritis classification criteria: an American College of Rheumatology/European League Against Rheumatism collaborative initiative. Arthritis Rheum. 2010;62:2569-81.

24. Vitali C, Bombardieri S, Jonsson R, Moutsopoulos HM, Alexander EL, Carsons SE, et al. Classification criteria for Sjogren's syndrome: a revised version of the European criteria proposed by the AmericanEuropean Consensus Group. Ann Rheum Dis. 2002;61:554-8.

25. Subcommittee for scleroderma criteria of the American Rheumatism Association Diagnostic and Therapeutic Criteria Committee. Preliminary criteria for the classification of systemic sclerosis (scleroderma). Arthritis Rheum. 1980;23:581-90.

26. Hochberg MC. Updating the American College of Rheumatology revised criteria for the classification of systemic lupus erythematosus. Arthritis Rheum. 1997;40:1725.

27. Bohan A, Peter JB. Polymyositis and dermatomyositis. N Engl J Med. 1975;292:344-7.

28. Tani C, Carli L, Vagnani S, Talarico R, Baldini C, Mosca M, et al. The diagnosis and classification of mixed connective tissue disease. J Autoimmun. 2014;48-49:46-9.

29. Watts R, Lane S, Hanslik T, Hauser T, Hellmich B, Koldingsnes W, et al. Development and validation of a consensus methodology for the classification of the ANCA-associated vasculitides and polyarteritis nodosa for epidemiological studies. Ann Rheum Dis. 2007;66:222-7.

30. Dasgupta B, Cimmino MA, Kremers HM, Schmidt WA, Schirmer M, Salvarani C, et al. 2012 Provisional classification criteria for polymyalgia rheumatica: a European League Against Rheumatism/American College of Rheumatology collaborative initiative. Arthritis Rheum. 2012;64:943-54.

31. Wallace ZS, Naden RP, Chari S, Choi H, Della-Torre E, Dicaire JF, et al. The 2019 American College of Rheumatology/European League Against Rheumatism Classification Criteria for IgG4-Related Disease. Arthritis Rheumatol. 2020;72:7-19.

32. Yamaguchi M, Ohta A, Tsunematsu T, Kasukawa R, Mizushima Y, Kashiwagi $\mathrm{H}$,et al. Preliminary criteria for classification of adult Still's disease. J Rheumatol. 1992;19:424-30.

33. Benhamou CL, Chamot AM, Kahn MF. Synovitis-acne-pustulosis hyperostosis-osteomyelitis syndrome (SAPHO). A new syndrome among the spondyloarthropathies? Clin Exp Rheumatol. 1988;6:109-12. 
34. Taylor W, Gladman D, Helliwell P, Marchesoni A, Mease P, Mielants H, CASPAR Study Group. Classification criteria for psoriatic arthritis: development of new criteria from a large international study. Arthritis Rheum. 2006;54:2665-73.

35. Heinle R, Chang C. Diagnostic criteria for sarcoidosis. Autoimmun Rev. 2014; 13:383-7. Behcet's Disease Research Committee of Japan. Behcet's disease guide to the diagnosis of Behcet's disease (1972) Japanese Journal of Ophthalmology. 1974; 18:291-294.

36. Jinnin M, Yamamoto T, Asano Y, Ishikawa O, Sato S, Takehara K, et al. Diagnostic criteria, severity classification and guidelines of eosinophilic fasciitis. J Dermatol. 2018;45:881-90.

37. Bashardoust B. Familial. Mediterranean fever; diagnosis, treatment, and complications. J Nephropharmacol. 2015;4:5-8.

38. Elgend HM, El Moghazy WM, Uemoto S, Fukuda K. Pre transplant serum magnesium level predicts outcome after pediatric living donor liver transplantation. Ann Transplant. 2012;17:29-37.

39. Badve SV, Palmer SC, Hawley CM, Pascoe EM, Strippoli GF, Johnson DW. Glomerular filtration rate decline as a surrogate end point in kidney disease progression trials. Nephrol Dial Transplant. 2016;31:1425-36.

40. Agus ZS. Hypomagnesemia. J Am Soc Nephrol. 1999;10:1616-22.

41. Maecker HT, McCoy JP, NUssenblatt R. Standardizing immunophenotyping for the Human Immunology Project. Nat Rev Immunol. 2012;12:191-200.

42. Tin A, Grams ME, Maruthur NM, Astor BC, Couper D, Mosley TH, et al. Results from the Atherosclerosis Risk in Communities study suggest that low serum magnesium is associated with incident kidney disease. Kidney Int. 2015;87:820-7.

43. Van Laecke S, Nagler EV, Verbeke F, Van Biesen W, Vanholder R. Hypomagnesemia and the risk of death and GFR decline in chronic kidney disease. Am J Med. 2013;126:825-31.

44. Sakaguchi Y, Shoji T, Hayashi T, Suzuki A, Shimizu M, Mitsumoto K, et al. Hypomagnesemia in type 2 diabetic nephropathy: a novel predictor of end-stage renal disease. Diabetes Care. 2012;35:1591-7.

45. Sakaguchi Y, Iwatani H, Hamano T, Tomida K, Kawabata H, Kusunoki Y, et al. Magnesium modifies the association between serum phosphate and the risk of progression to end-stage kidney disease in patients with non-diabetic chronic kidney disease. Kidney Int. 2015;88:833-42.

46. Ravell J, Chaigne-Delalande B, Lenardo M. X-linked immunodeficiency with magnesium defect, Epstein-Barr virus infection, and neoplasia disease: a combined immune deficiency with magnesium defect. Curr Opin Pediatr. 2014;26:713-9.

47. Salem M, Kasinski N, Munoz R, Chernow B. Progressive magnesium deficiency increases mortality from endotoxin challenge: protective effects of acute magnesium replacement therapy. Crit Care Med. 1995;23:108e18.

48. Van Laecke S, Vermeiren P, Nagler EV, Caluwe R, De Wilde M, Van der Vennet M, et al. Magnesium and infection risk after kidney transplantation: An observational cohort study. J Infect. 2016;73:817. 
Figures
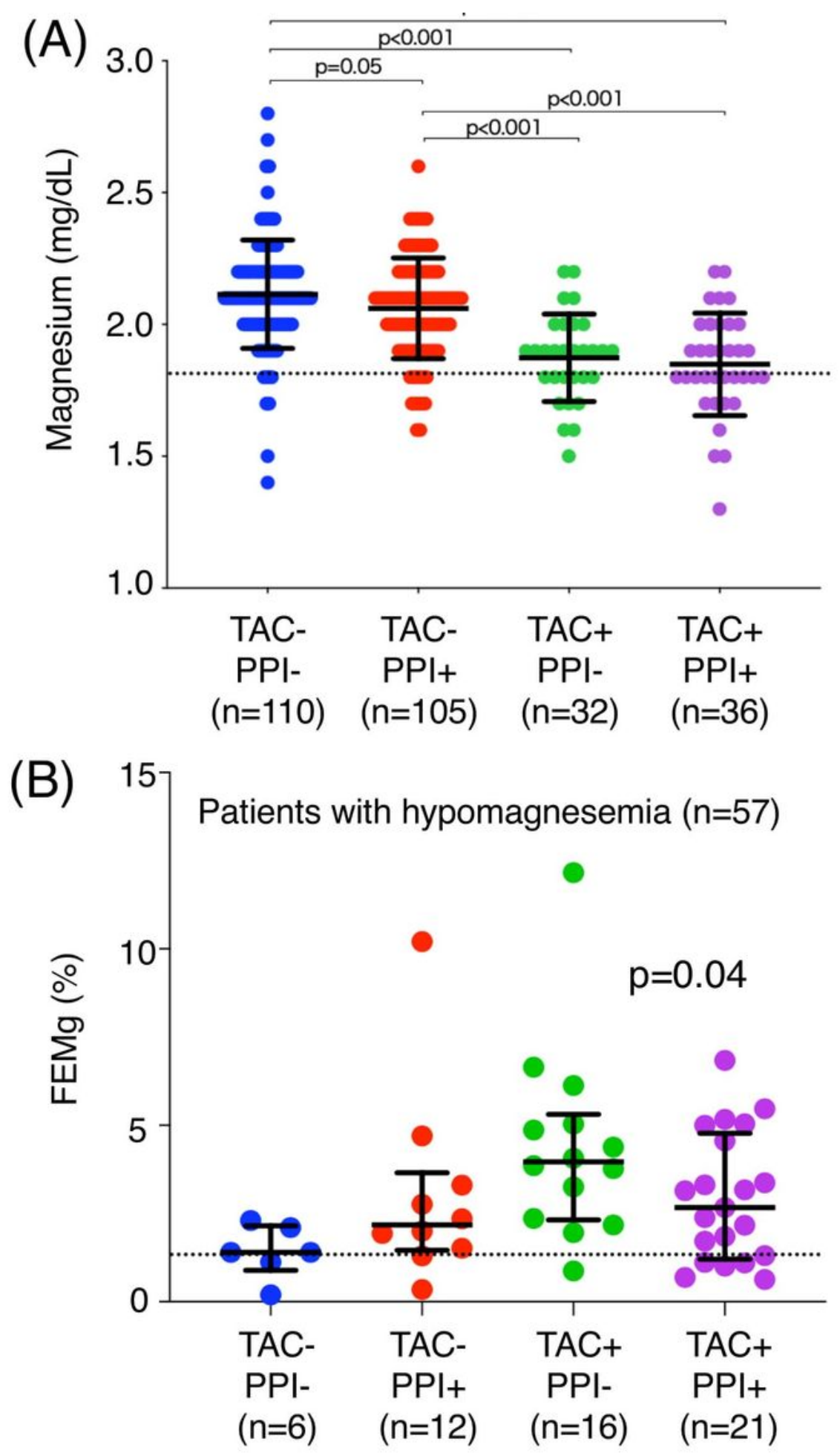

Figure 1 
Comparison of magnesium level and fraction excretion of magnesium by drug use. All patients were divided into 4 groups according to tacrolimus and proton pump inhibitor use. Comparison of serum $\mathrm{Mg}$ levels among the 4 groups isre shown (A). Dotted line indicates the normal limit of magnesium level (1.8 $\mathrm{mg} / \mathrm{dL}$ ). Comparison of FEMg in patients with hypomagnesemia is shown (B). Dotted line indicates the normal limit of FEMg (2.0\%). FEMg, fractional excretion of magnesium; TAC, tacrolimus; PPI, proton pump inhibitors.
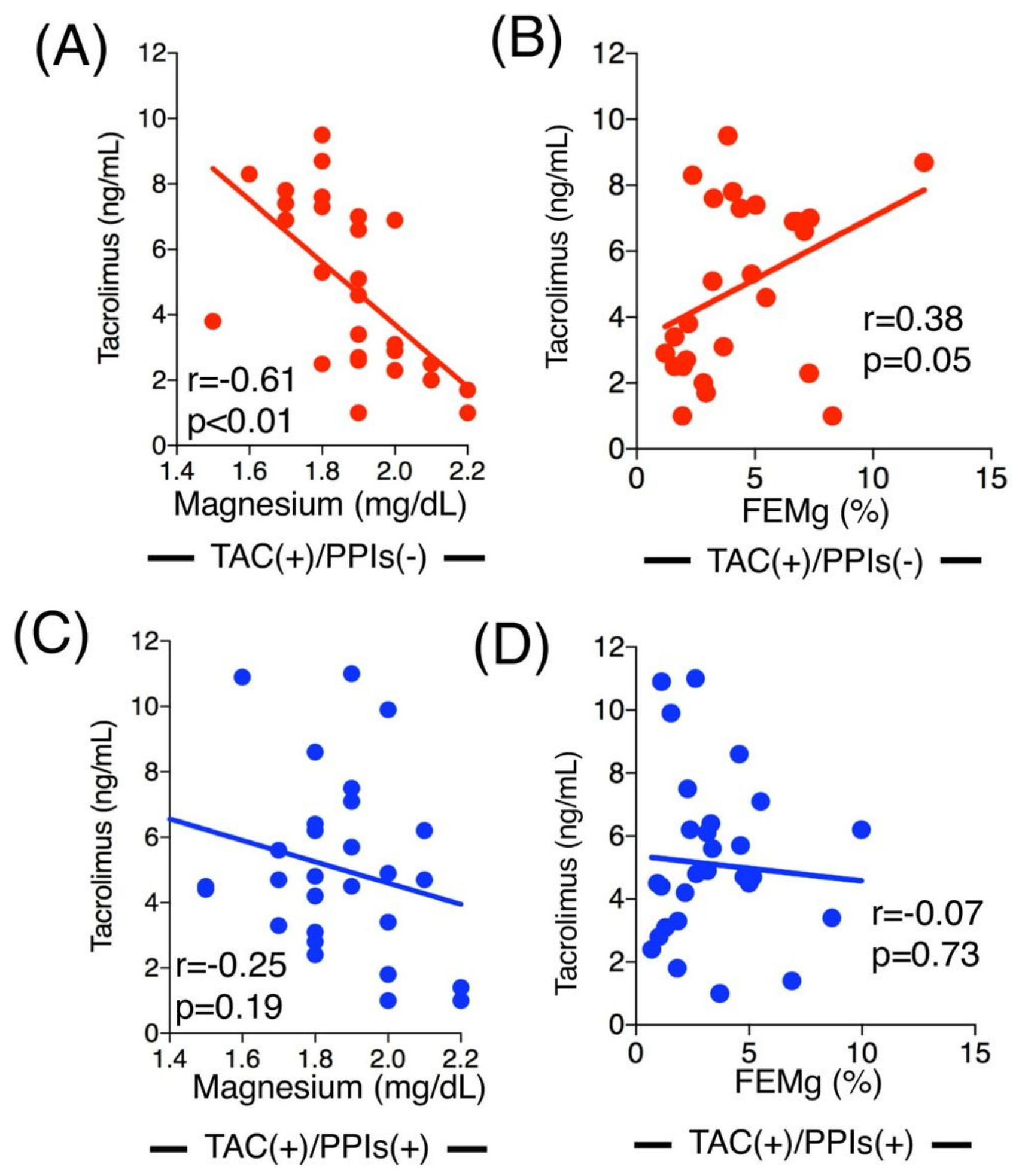

- TAC(+)/PPIs(+) -

Figure 2 
Association between tacrolimus concentration and magnesium level or fractional excretion of magnesium by drug use. In patients without PPI, TAC concentration was significantly correlated with $\mathrm{Mg}$ level $(r=-0.61, p<0.01)(A)$ and FEMg $(r=0.38, p=0.05)(B)$. In patients treated with both TAC and PPI, in contrast, no association was seen between TAC concentration and $\mathrm{Mg}$ level $(r=0.25, p=0.19)$ (C) or FEMg $(r=-0.07, p=0.73)(D)$. FEMg, fractional excretion of magnesium; TAC, tacrolimus; PPI, proton pump inhibitor.
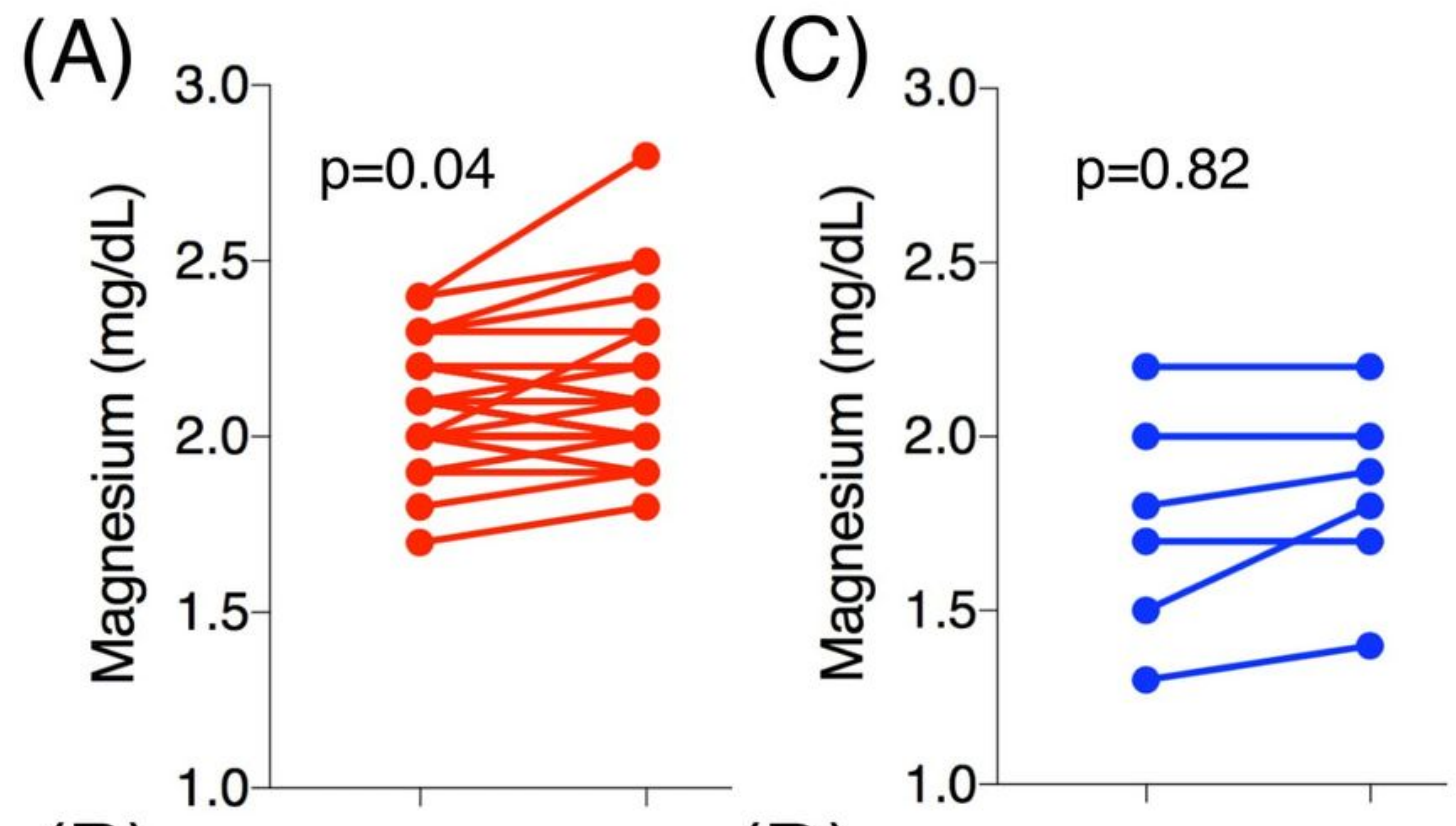

(B)
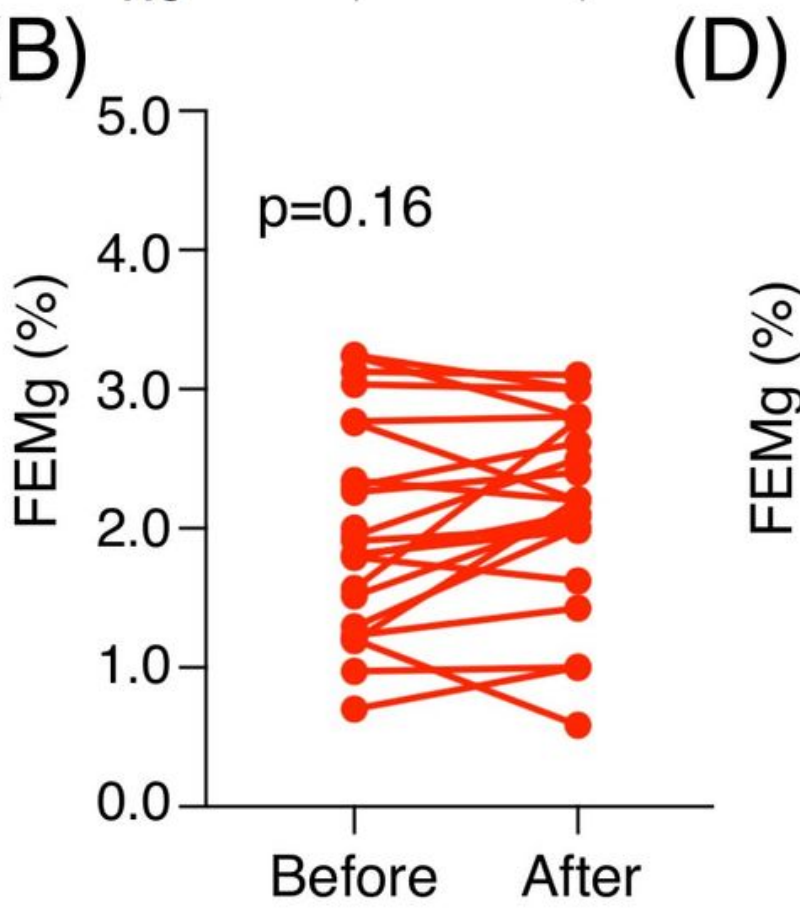
Discontinuation of PPIs - TAC(-)/PPIs $(+)$ -

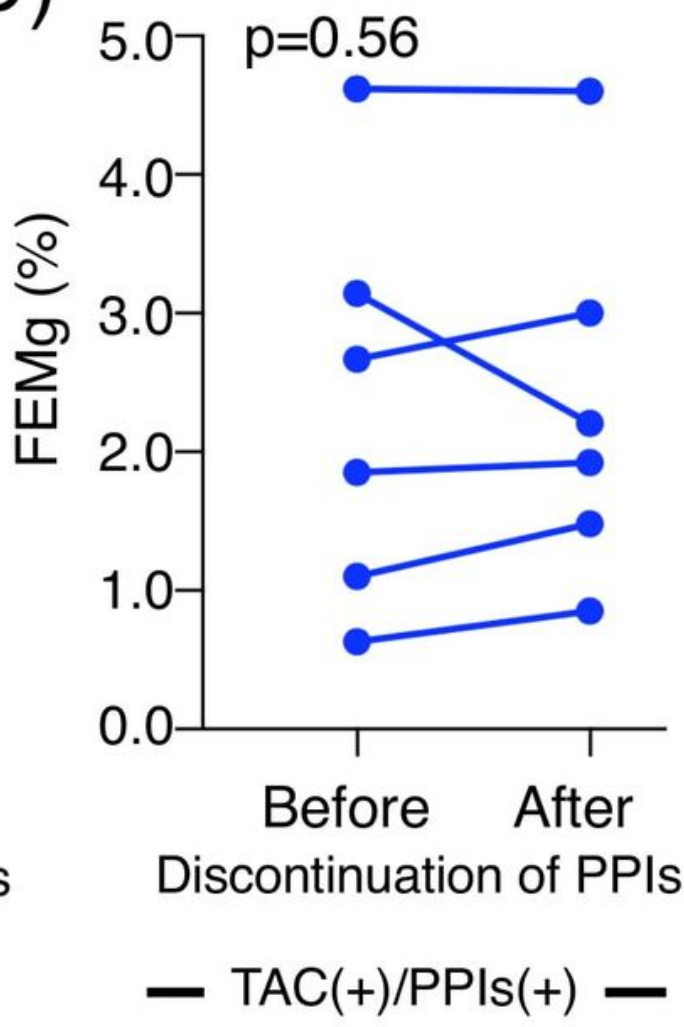

Figure 3 
Serial change in magnesium level after discontinuation of proton pump inhibitor. Magnesium level was significantly increased after discontinuation of PPI in patients without TAC $(p=0.04)(A)$, but no significant difference was seen in FEMg (B). In patients with TAC, no change in magnesium level or FEM was observed after PPI discontinuation (C, D). FEMg, fractional excretion of magnesium; TAC, tacrolimus; PPI, proton pump inhibitor.

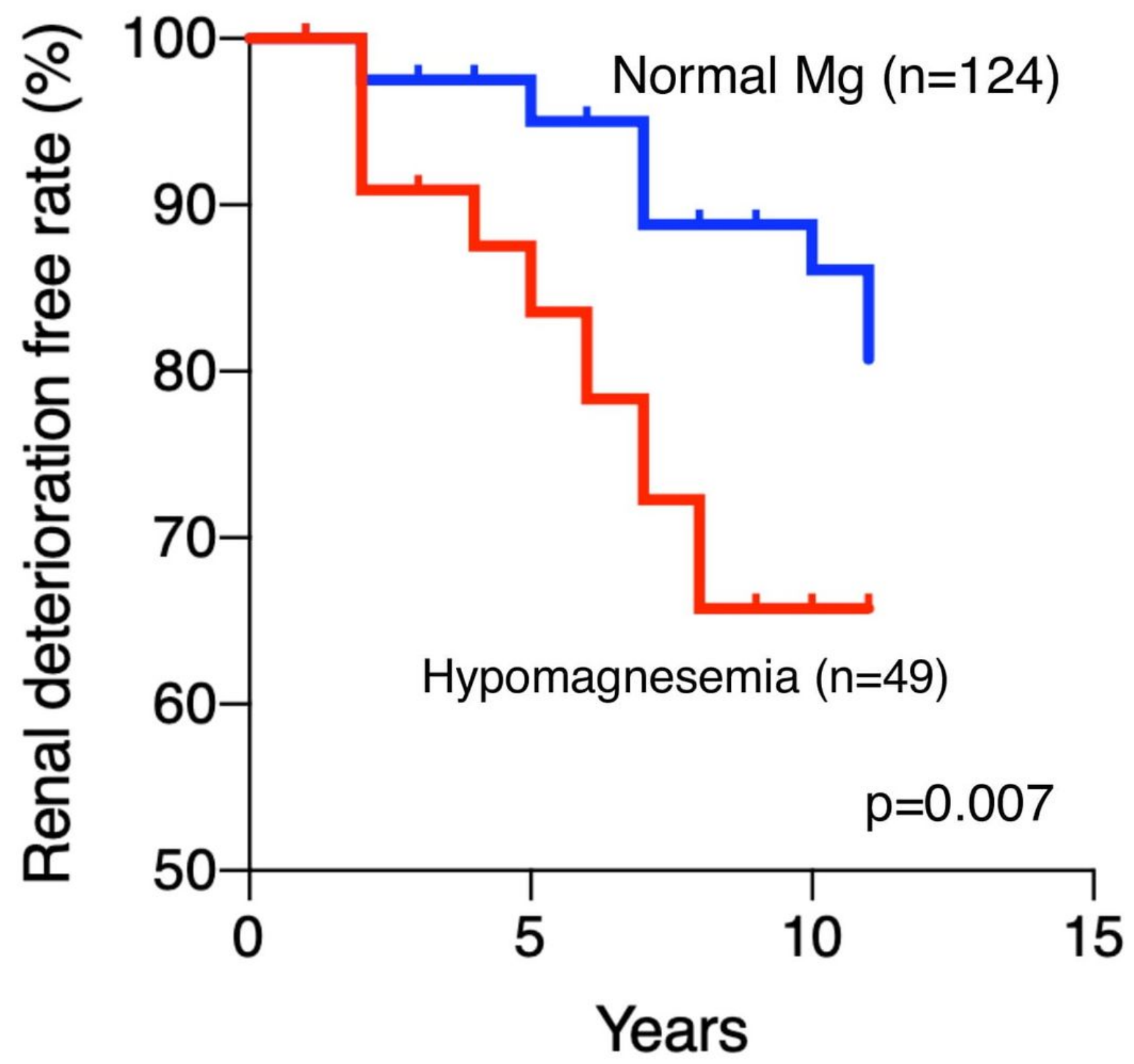

Figure 4

Cumulative renal deterioration-free rate. A significantly lower renal deterioration-free rate was observed in patients with hypomagnesemia compared to patients with normal $\mathrm{Mg}(\mathrm{p}=0.007)$. Mg, magnesium; TAC, tacrolimus; PPI, proton pump inhibitor. 


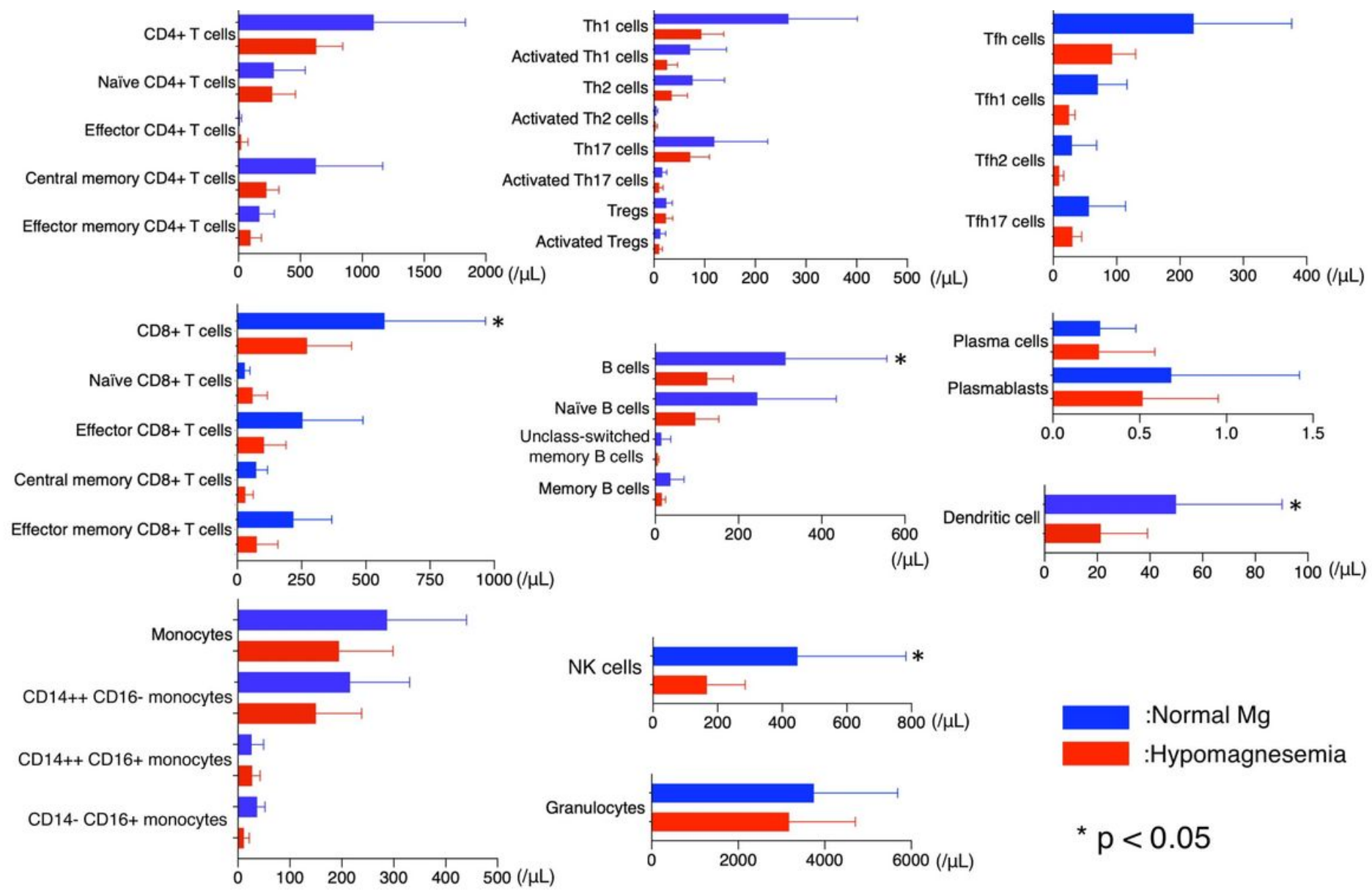

\section{Figure 5}

Flow cytometric analysis in patients with and without hypomagnesemia. Lower counts for CD8+ T cells, CD19+ B cells, NK cells, and dendritic cells were observed in patients with hypomagnesaemia $(p=0.03$, $p=0.02, p=0.02$, and $p=0.03$, respectively).

\section{Supplementary Files}

This is a list of supplementary files associated with this preprint. Click to download.

- SuppleTableHanaokaH.docx 